\title{
Identification and Molecular Characterization of Nuclear Citrus leprosis virus, a Member of the Proposed Dichorhavirus Genus Infecting Multiple Citrus Species in Mexico
}

\author{
Avijit Roy, Andrew L. Stone, Jonathan Shao, Gabriel Otero-Colina, Gang Wei, Nandlal Choudhary, Diann Achor, \\ Laurene Levy, Mark K. Nakhla, John S. Hartung, William L. Schneider, and Ronald H. Brlansky
}

\begin{abstract}
First, sixth, seventh, and twelfth authors: University of Florida, IFAS, Plant Pathology Department, Citrus Research and Education Center, 700 Experiment Station Road, Lake Alfred, FL; second and eleventh authors: United States Department of Agriculture-Agricultural Research Service (USDA-ARS), Foreign Disease-Weed Science Research Unit (FDWSRU), Fort Detrick, MD; third and tenth authors: USDA-ARS, Molecular Plant Pathology Laboratory (MPPL), Beltsville, MD; fourth author: Colegio de Postgraduados, Campus Montecillo, Texcoco, Edo. De Mex., CP 56230, México; fifth and ninth authors: USDA-Animal and Plant Health Inspection Service (APHIS)-Plant Protection and Quarantine (PPQ)Center for Plant Health Science and Technology (CSIRO), Beltsville, MD; and eighth author: USDA-APHIS-PPQ-CPHST, Riverdale, MD. Current address of first author: USDA-ARS, FDWSRU, Fort Detrick, MD.
\end{abstract}

Accepted for publication 17 November 2014.

\section{ABSTRACT}

Roy, A., Stone, A. L., Shao, J., Otero-Colina, G., Wei, G., Choudhary, N., Achor, D., Levy, L., Nakhla, M. K., Hartung, J. S., Schneider, W. L., and Brlansky, R. H. 2015. Identification and molecular characterization of nuclear Citrus leprosis virus, a member of the proposed Dichorhavirus genus infecting multiple Citrus species in Mexico. Phytopathology 105:564-575.

Citrus leprosis is one of the most destructive diseases of Citrus spp. and is associated with two unrelated virus groups that produce particles primarily in either the cytoplasm or nucleus of infected plant cells. Symptoms of leprosis, including chlorotic spots surrounded by yellow haloes on leaves and necrotic spots on twigs and fruit, were observed on leprosis-affected mandarin and navel sweet orange trees in the state of Querétaro, Mexico. Serological and molecular assays showed that the cytoplasmic types of Citrus leprosis virus (CiLV-C) often associated with leprosis symptomatic tissues were absent. However, using transmission electron microscopy, bullet-shaped rhabdovirus-like virions were observed in the nuclei and cytoplasm of the citrus leprosis-infected leaf tissues. An analysis of small RNA populations from symptomatic tissue was carried out to determine the genome sequence of the rhabdovirus-like particles observed in the citrus leprosis samples. The complete genome sequence showed that the nuclear type of CiLV (CiLV-N) present in the samples consisted of two negative-sense RNAs: 6,268-nucleotide (nt)long RNA1 and 5,847-nt-long RNA2, excluding the poly(A) tails. CiLV-N had a genome organization identical to that of Orchid fleck virus (OFV), with the exception of shorter 5' untranslated regions in RNA1 (53 versus $205 \mathrm{nt}$ ) and RNA2 (34 versus $182 \mathrm{nt}$ ). Phylogenetic trees constructed with the amino acid sequences of the nucleocapsid $(\mathrm{N})$ and glycoproteins $(\mathrm{G})$ and the RNA polymerase (L protein) showed that CiLV-N clusters with OFV. Furthermore, phylogenetic analyses of $\mathrm{N}$ protein established CiLV-N as a member of the proposed genus Dichorhavirus. Reversetranscription polymerase chain reaction primers for the detection of CiLV-N were designed based on the sequence of the $\mathrm{N}$ gene and the assay was optimized and tested to detect the presence of CiLV-N in both diseased and symptom-free plants.
Citrus leprosis disease is associated with two distinct viruses, referred to as cytoplasmic and nuclear Citrus leprosis virus (CiLV-C and CiLV-N, respectively). Known cytoplasmic types CiLV-C $(29,37)$ and Citrus leprosis virus C2 (CiLV-C2) (45) produce particles primarily in the cytoplasm of infected cells, whereas CiLV-N produces particles primarily in the nucleus of infected cells $(2,50)$. CiLV-C and CiLV-C2 belong to the genus Cilevirus, while CiLV-N is one of the members of the proposed genus Dichorhavirus. Recently, another Cilevirus sp. closely related to CiLV-C2 was reported from Hawaii, infecting Hibiscus spp., but no experimental host range was documented to confirm the capability of that virus to infect citrus (35). Both cytoplasmic and nuclear type CiLV are transmitted by tenuipalpid false spider mites (Brevipalpus spp.) (44). CiLV-C is much more prevalent and destructive and has been reported from several South and Central American countries, whereas the occurrence of CiLV-N is rare (2). However, CiLV-N has

Corresponding author: R. H. Brlansky; E-mail address: rhby@ufl.edu

*The $e$-Xtra logo stands for "electronic extra" and indicates that four supplementary figures and one supplementary table are published online.

http://dx.doi.org/10.1094/PHYTO-09-14-0245-R

(C) 2015 The American Phytopathological Society been reported from the states of São Paulo, Rio Grande do Sul, and Minas Gerais in Brazil; Boquete in Panama; and Casanare in Colombia $(2,46)$. Although citrus leprosis was once a major citrus disease problem in Florida, there have been no reports of leprosis in the United States since 1968 (4).

Citrus leprosis is a nonsystemic viral disease of Citrus spp. which presents as localized lesions on the leaves, fruit, stems, or twigs. Chlorotic lesions on leaves, often with necrotic centers and yellow haloes, and necrotic ring spots with a central depression on fruit and necrotic lesions on twigs are characteristic symptoms of citrus leprosis disease. When infestations of viruliferous mites are not controlled, lesions in the petiole cause severe defoliation, whereas lesions in the peduncle promote intense fruit drop, and coalesced necrotic lesions induce the death of the twigs. In the absence of mite control, plants may die within 3 to 5 years. No significant differences between fruit and stem lesions caused by CiLV-C, $-\mathrm{C} 2$, and $-\mathrm{N}$ have been observed but minor differences in foliar lesions have been noticed. Foliar lesions caused by the cytoplasmic CiLVs are larger in size than those caused by the nuclear CiLVs. Lesions caused by CiLV-C tended to have a pale green color, with one or more concentric gummy rings, whereas lesions of CiLV-N tend to have dark centers surrounded by intermediate orange haloes and outer, bright-yellow haloes (33). 
In 2005, citrus leprosis disease was first reported in 'Valencia' and 'Hamlin' sweet orange in Chiapas, the southernmost state of Mexico. Thereafter, leprosis was reported from Huimanguillo and Cunduacan, in the state of Tabasco, which borders Chiapas. Ultrastructural examination by transmission electron microscopy (TEM) and molecular detection by reverse-transcription polymerase chain reaction (RT-PCR) identified CiLV-C associated with leprosis symptoms in Mexico (16). In addition to TEM and RTPCR, symptom-based diagnosis of CiLV-C and -C2 can be confirmed by enzyme-linked immunosorbent assay (ELISA) utilizing CiLV-C- or CiLV-C2-specific polyclonal antibodies (PAbs) or monoclonal antibodies (6,7). In 2012, samples with citrus leprosis symptoms were collected from several locations in Mexico and were tested by CiLV-C- and CiLV-C2-specific ELISA $(6,7)$ and RT-PCR $(28,45)$; however, these tests failed to identify the virus associated with the leprosis samples received from the state of Querétaro. However, TEM evaluation of the samples revealed bullet-shaped rhabdovirus-like particles in the nucleus and cytoplasm. Therefore, it was suspected that the virus associated with the citrus leprosis disease symptoms in Querétaro state of Mexico may be associated with CiLV-N.

The genome of viral pathogens can be rapidly determined utilizing next-generation sequencing (NGS) (47). Reduced costs and increased accessibility of NGS technologies have enabled its practical application in plant virology. Recent examples of NGS applied to citrus virus genome sequence determination include Citrus chlorotic dwarf virus (31), CiLV-C2 (45), Citrus vein enation virus (58), Citrus yellow vein clearing virus (30), and an endogenous pararetrovirus genome from 'Carrizo' citrange (48). In this study, we utilized NGS to sequence small RNA (sRNA) molecules derived from viral genomes that have accumulated in leprosis affected tissues due to antiviral defense. Bioinformatic tools $(45,47)$ were then utilized to assemble the sequence reads to determine the complete genome sequence of CiLV-N associated with leprosis disease in the state of Querétaro, Mexico. The CiLV-N isolate from Mexico was serologically and molecularly characterized, and specific primers for CiLV-N were utilized for RT-PCR assays.

\section{MATERIALS AND METHODS}

Sources of leprosis virus-infected and healthy plant materials. Citrus leaf, fruit, and twig samples from healthy plants and with leprosis disease symptoms were collected from seven Citrus spp.: grapefruit (Citrus $\times$ paradisi), lemon (Citrus $\times$ limon), lime (Citrus aurantiifolia), mandarin (C. reticulata), sour orange (C. aurantium), sweet or navel lime (C. limetta), and sweet orange (Citrus $\times$ sinensis) in Querétaro, Mexico and shipped under permit to the United States Department of Agriculture (USDA)-APHISPPQ-CPHST laboratory in Beltsville, MD for serological and molecular testing. Upon arrival, the samples were washed with water and air dried, and necrotic lesions ( 3 to $5 \mathrm{~mm}$ in diameter) with chlorotic haloes or chlorotic green lesion with outside yellow haloes (6 to $9 \mathrm{~mm}$ in diameter) were excised using disposable stainless-steel razor blades. Healthy sweet orange leaf samples were used as negative controls.

Double-antibody sandwich enzyme-linked immunosorbent assay. Double-antibody sandwich enzyme-linked immunosorbent assay (DAS-ELISA) was carried out as described by Choudhary et al. (7). Citrus leprosis disease samples were divided into two categories: small necrotic lesions with chlorotic haloes and large chlorotic green lesions with outside yellow haloes. Both types of leprosis lesions were excised and then homogenized in $1 \times$ phosphate-buffered saline (PBS) extraction buffer $(\mathrm{pH} 7.4)$ at a 1: 20 dilution (wt/vol). Diluted crude extracts of leprosis lesions were tested with CiLV-C-, CiLV-C2-, and Orchid fleck virus (OFV)specific PAb using DAS-ELISA $(7,24)$ and "unpublished results". A 1:500 dilution of the OFV PAb and 1:1000 dilution of the CiLV-C or
CiLV-C2 PAbs were used. To check the PAb against nucleocapsid (N) protein of OFV, an expressed OFV $\mathrm{N}$ protein was used as positive control (courtesy of Dr. H. Kondo). Similarly, PAbs of CiLV-C and CiLV-C2 were tested against the putative coat protein gene of positive Mexican and Colombian cytoplasmic citrus leprosis isolates. Tissues from healthy sweet orange leaves were used as negative controls. In DAS-ELISA, citrus leprosis tissues were considered positive for CiLV-C, CiLV-C2, or OFV infection if the average optical density at $405 \mathrm{~nm}\left(\mathrm{OD}_{405}\right)$ absorbance values were at least three times higher than $\mathrm{OD}_{405}$ values of the negative control.

RT-PCR. Total nucleic acids were isolated from $100 \mathrm{mg}$ of healthy citrus tissue as well as from leprosis disease-affected citrus leaves (equivalent to 6 to 12 lesions) using the plant RNeasy mini kit (Qiagen, Valencia, CA) and stored at $-20^{\circ} \mathrm{C}$ for future use. Primer pairs specific to the CiLV-C movement protein (MP) gene (RNA2, p32) (28), the CiLV-C2 putative coat protein gene (RNA1, p29) (45), and the Hibiscus green spot virus 2 (HGSV-2) putative polyprotein (RNA1, p273) (34) were used to amplify the target genes from CiLV-C-, CiLV-C2-, and HGSV-2-infected isolates following the published RT-PCR protocol (45). In addition, specific primers for the hibiscus-infecting Cilevirus sp. (35) and several pairs of OFV-specific primers (18) also were utilized to assess the presence of viruses related to CiLV-C2 or OFV.

Preparation of leaf samples for TEM. Citrus samples displaying citrus leprosis disease symptoms and suspected to contain the nuclear CiLV form of the virus were sampled from mandarin and navel sweet orange trees in the Querétaro state of Mexico. Samples were taken from the yellow halo surrounding chlorotic or necrotic leprosis lesions following the previously described protocol (45). Healthy and leprosis-affected tissues were fixed in 3\% glutaraldehyde in Sorenson's phosphate buffer (0.066 $\mathrm{M}), \mathrm{pH} 6.8$, for $24 \mathrm{~h}$ at $4^{\circ} \mathrm{C}$. The glutaraldehyde was removed with three washes with phosphate buffer and then the fixed samples were shipped to the Citrus Research and Education Center, Lake Alfred, FL. Upon arrival, each vial was again washed three times with PBS as above and post fixed in $2 \%$ osmium tetroxide for $4 \mathrm{~h}$ at room temperature. The fixed tissues were then rinsed twice in PBS wash buffer, dehydrated in a $10 \%$ graded acetone series, followed by more than 3 days of infiltration before they were embedded in Spurr's resin. Ultrathin sections of leaves were obtained with a diamond knife using an LKB Huxley ultramicrotome (LKB Instruments, Ltd., Rockville, MD). After placing the sections on 200-mesh Formvar-coated copper grids, $2 \%$ aqueous uranyl acetate followed by Reynold's lead citrate was used to stain the grids. Observations and micrographs were done on a Morgagni 268 transmission electron microscope (FEI Company, Hillsboro, OR).

SRNA NGS. Total RNA was extracted from healthy and citrusleprosis-diseased plants. The RT-PCR experiments with these RNA templates failed to produce any amplicons with any of the CiLV-C-, CiLV-C2-, HGSV-2-, and OFV-specific primers. Two composite samples of total RNA, one from mandarin (M2345) and another from navel sweet orange (N16810), were isolated using the RNeasy Plant Mini Kit (Qiagen) and then shipped to Fasteris SA, Switzerland for sRNA NGS using the Illumina GA IIX platform. Two libraries were constructed and sequenced, with reads of 17 to 44 nucleotides (nt). Reads were mapped using the short read aligner Bowtie (version 0.12.7) (27) to the database of citrus genome sequences (C. sinesis_v1.0, http://www.citrusgenomedb.org/). Millions of reads also were checked using bowtie against plant viruses available in the National Center for Biotechnology Information (NCBI) GenBank, and the identity of the virus associated with nuclear leprosis symptoms was confirmed utilizing the subtractive approach (47). To assemble the sRNA sequences into longer contigs, the Velvet Assembler version 1.2.07 was used, with a k-mer of 15 (65). These larger contigs were compared with the nonredundant protein database using BlastX (http://blast.ncbi .nlm.nih.gov/Blast.cgi). To complete the genome sequence of the virus associated with leprosis disease in Querétaro, Mexico, 
multiple RT-PCR primers were designed and utilized to bridge the gaps ( 77 to $953 \mathrm{nt}$ ) between the contigs. Molecular cloning followed by Sanger sequencing was undertaken to confirm the NGS data. Overall, approximately $1.4-$ to $2.0-\mathrm{kb}$ overlapping RT-PCR amplicons were amplified (Table 1). Amplicons were cloned using a TOPO TA Cloning Kit (Life Technologies, Carlsbad, CA) following the manufacturer's protocol, and at least five clones per amplicon were bidirectionally sequenced using an ABI Prism 3100 automatic DNA Sequencer (DNA Sequencing Core Laboratory, Gainesville, FL). BLAST2 sequences (bl2seq) were used to align the overlapping sequences and complete the genome sequence of CiLV-N excluding the $5^{\prime}$ and $3^{\prime}$ untranslated regions (UTRs).

The RNA ligase-mediated rapid amplification of cDNA ends (RLM-RACE) kit (Ambion; Life Technologies) was utilized to determine the $5^{\prime}$ and $3^{\prime}$ UTRs of negative-sense CiLV-N-RNA1 and -RNA2 following the manufacturer's described protocol. The 5' and $3^{\prime}$ RACE gene-specific outer and inner reverse primers specific to the CiLV-N-RNA1 or -RNA2 sequences were designed and utilized (Table 1). The outer and inner $5^{\prime}$ and $3^{\prime}$ RLM-RACE PCR amplicons were obtained by amplifying the terminal mRNA sequences in RT-PCR. The RACE amplicons were cloned in the TOPO TA cloning vector, and at least 5 to 10 clones for each terminus were bidirectionally sequenced.

Phylogenetic analysis. To identify phylogenetic relationships among CiLV-N samples, three cladograms were constructed using the conserved amino acid sequences of the $\mathrm{N}$ proteins, glycoproteins (G), and long polymerase (L) proteins of several plant- and animalinfecting rhabdoviruses. All full-length protein sequences used in the construction of cladograms were obtained from NCBI GenBank. The sequences were aligned using ClustalW in the MEGA6 package (http://www.megasoftware.com). Cladograms were constructed using both the neighbor-joining and maximum-parsimony methods supported by 1,000 bootstrap replicates with a $70 \%$ cut off value and other default parameters applied in parallel (55).
Similarity plot. A similarity plot was made using the concatenated N, G, and L proteins for each rhabdovirus: Citrus necrotic spot virus (CiNSV), Coffee ring spot virus (CoRSV), Maize fine streak virus (MFSV), OFV, Potato yellow dwarf virus (PYDV), and Sonchus yellow net virus (SYNV). The concatenated proteins for each virus were aligned pairwise with CiLV-N using the SmithWaterman Algorithm (gap opening 10, gap extension 0.5 in the European Molecular Biology Open Software Suite) (http://emboss .sourceforge.net). This alignment was further used as input into the Plotcon software program (http://emboss.bioinformatics.nl/cgi-bin/ emboss/plotcon) with a window size of 50 to generate the similarity plot between CiLV-N and each studied virus.

Development of an RT-PCR assay for the specific detection of the CiLV-N. Total RNA was extracted from healthy mandarin or Valencia sweet orange leaves and the leaves with citrus leprosis disease symptoms. In total, RNA from 26 CiLV-N suspected samples from seven Citrus spp. (grapefruit, lime, lemon, mandarin, sour orange, sweet lime, and sweet orange) were extracted using the RNeasy Plant Mini Kit (Qiagen). All samples were analyzed for the presence of CiLV-C, CiLV-C2, hibiscus-infecting Cilevirus sp. closely related to $\mathrm{CiLV}-\mathrm{C} 2$, HGSV-2, and OFV following the previously described RT-PCR protocol (45). CiLV-N protein N gene (RNA1-open reading frame [ORF]1)-specific forward and reverse primers (46) were utilized for detection of CiLV-N from Querétaro, Mexico following the standard RT-PCR protocol (45). RT-PCR products were sequenced to confirm the identity of the virus and the sequences were compared with sequences from known plant-pathogenic rhabdoviruses.

\section{RESULTS}

Symptoms of nuclear-type leprosis in Mexico. Mandarin and navel sweet orange leaves with characteristic citrus leprosis disease lesions were collected in Querétaro, Mexico. Two distinct leprosis lesions were observed. Navel sweet orange lesions had

TABLE 1. Primer sequences used to amplify the complete genomes RNA1 and RNA2 of nuclear Citrus leprosis virus (CiLV-N)

\begin{tabular}{|c|c|c|c|c|c|}
\hline Number & Name & Primer sequence $\left(\text { position } 5^{\prime}-3^{\prime}\right)^{\mathrm{a}}$ & Strand & Amplicon size $(n t)^{b}$ & $\begin{array}{c}\text { Overlapping } \\
\text { nucleotides }\end{array}$ \\
\hline \multicolumn{6}{|l|}{ RNA1 } \\
\hline 1 & CiLN-5' RACE-gsOP-R & ${ }^{768}$ TCATGAATGACTCAGCAGGCTTCA ${ }^{745}$ & Antisense & $\ldots$ & $\ldots$ \\
\hline 2 & CiLN-5' RACE-gsIP-R & ${ }^{563}$ CATGGTCATGGTCTCCAGGAATGA ${ }^{540}$ & Antisense & $\ldots$ & 540 \\
\hline 3 & CiLN-R1.F1 & ${ }^{24}$ CTTCTAGTGCAAGTGGCAGAAATGAC 49 & Sense & 1,421 & $\ldots$ \\
\hline 4 & CiLN-R1.R1 & 1444 TTGTAGAGTTTGCGGGACACAGG ${ }^{1422}$ & Antisense & $\ldots$ & 664 \\
\hline 5 & CiLN-R1.2F2 & ${ }^{781}$ AGATCAAACAGGCATATTCGGTCCT ${ }^{805}$ & Sense & 1,466 & $\ldots$ \\
\hline 6 & CiLN-R1.2R2 & ${ }^{2251}$ GTGTAACACCCAGTTGAGCACTAGAT ${ }^{2226}$ & Antisense & $\ldots$ & 358 \\
\hline 7 & CiLN-R1.F3 & ${ }^{2026}$ CATGTCATCACTCATTGACCAGCTG ${ }^{2050}$ & Sense & 1,505 & $\ldots$ \\
\hline 8 & CiLN-R1.R3 & ${ }^{3530}$ TTATCCCTTTCATTATGGACCCTGCA ${ }^{3505}$ & Antisense & $\ldots$ & 407 \\
\hline 9 & CiLN-R1.F4 & ${ }^{3124}$ AGTCCAATACACATCATCCTCCAAGC 3149 & Sense & 1,966 & $\ldots$ \\
\hline 10 & CiLN-R1.R4 & ${ }^{5089}$ GCTCGTAAAGAACCGTTATCCCTCTT ${ }^{5064}$ & Antisense & $\ldots$ & 673 \\
\hline 11 & CiLN-R1.F6 & ${ }^{4417}$ TCCTATCAGACGTGGATGATTACTTACG ${ }^{4444}$ & Sense & 1,633 & $\ldots$ \\
\hline 12 & CiLN-R1.R6 & ${ }^{6049}$ ATGCCCACAGGAAGACTTTGATGAT ${ }^{6025}$ & Antisense & $\ldots$ & $\ldots$ \\
\hline 13 & CiLN-3' RACE-gsOP-F & ${ }^{5887}$ GAGAAAGTCCTAAGCCACTCTCATGT ${ }^{5912}$ & Sense & $\ldots$ & 139 \\
\hline 14 & CiLN-3' RACE-gsIP-F & ${ }^{5949}$ GTTGCACTCGTTCATTGGTATGTTCA ${ }^{5974}$ & Sense & $\ldots$ & 77 \\
\hline \multicolumn{6}{|c|}{ 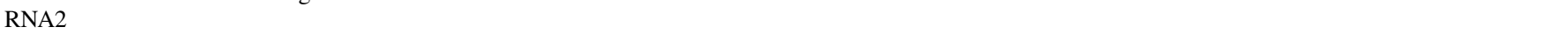 } \\
\hline 1 & 2CiLN-5' RACE-gsOP-R & ${ }^{811}$ CTGTCATTGATCATCAGATGACACCAAC ${ }^{784}$ & Antisense & $\ldots$ & $\ldots$ \\
\hline 2 & 2CiLN-5' RACE-gsIP-R & ${ }^{578}$ CATTATCCCTGTTTTGTCATCGTCGTG ${ }^{552}$ & Antisense & $\ldots$ & 389 \\
\hline 3 & CiLN-R2.F1 & ${ }^{190}$ CACTGTTTCAGGAATGTTACACAGAGTC ${ }^{217}$ & Sense & 1,807 & $\ldots$ \\
\hline 4 & CiLN-R2.R1 & ${ }^{1996}$ TCTTCCCTCATCTGTTGGTTCCATT ${ }^{1972}$ & Antisense & $\ldots$ & 1,056 \\
\hline 5 & CiLN-R2.F2 & ${ }^{941}$ CACTCTGAGAATCATTCAGCTAGGTGA ${ }^{967}$ & Sense & 1,542 & $\ldots$ \\
\hline 6 & CiLN-R2.R2 & ${ }^{2482}$ TTGAAGAACATGAGTAGGTTGGGTGAA 2456 & Antisense & $\ldots$ & 456 \\
\hline 7 & CiLN-R2.F3 & ${ }^{2027}$ TAGACTGTTCGGTTACACCAATCTGG ${ }^{2052}$ & Sense & 1,587 & $\ldots$ \\
\hline 8 & CiLN-R2.R3 & ${ }^{3613}$ TCCTTGGTATACGAGCCCATGTAAAC 3588 & Antisense & $\ldots$ & 286 \\
\hline 9 & CiLN-R2.F4 & ${ }^{3328}$ GACAGGAACGACACTGCATGAGTTA ${ }^{3352}$ & Sense & 1,554 & $\ldots$ \\
\hline 10 & CiLN-R2.R4 & ${ }^{4881}$ TGTCCATCATTTCGAACAACTGGACA ${ }^{4856}$ & Antisense & $\ldots$ & 618 \\
\hline 11 & CiLN-R2.F5 & ${ }^{4264}$ CAGTGATATCGTCCAGTGAGTCCA ${ }^{4287}$ & Sense & 1,500 & $\ldots$ \\
\hline 12 & CiLN-R2.R5 & ${ }^{5763}$ GAGTTACTCTGAATAGCTCTCTCACGTC ${ }^{5736}$ & Antisense & $\ldots$ & $\cdots$ \\
\hline 13 & 2CiLN-3' RACE-gsOP-F & ${ }^{5093}$ TGAAGCTGCCTGTGACTTCATATGTAT ${ }^{5119}$ & Sense & $\ldots$ & 671 \\
\hline 14 & 2CiLN-3' RACE-gsIP-F & ${ }^{5562}$ ACTAAGAAGGCAAAGGAGCTGATGT 5586 & Sense & $\ldots$ & 202 \\
\hline
\end{tabular}

${ }^{a}$ Nucleotide positions of the primers in the genomic RNA1 and RNA2 of CiLV-N isolate M2345 (GenBank accession KF209275 and KF209276).

b Amplicon size in nucleotides (nt). 
necrotic centers, often with an intermediate green haloes with outside yellow haloes (Fig. 1C), whereas typical intermediate orange-colored haloes and external chlorotic haloes as described by Marques et al. (33) for CiLV-N also were observed in infected mandarin leaves (Fig. 1H). Brown to black raised lesions were observed on young and mature twigs, respectively (Fig. 1I). The initial stages of infection on immature fruit produced small brown lesions surrounded by large yellow haloes (data not shown) whereas, in mature fruit, the yellow haloes disappeared or were reduced in size and only dark-brown necrotic spots with central depressions were observed (Fig. 1J). In advanced stages of infection, small lesions often coalesced. Symptoms varied on the different citrus hosts sampled; however, there was no one specific and established host-symptom relationships. In an attempt to establish virus-host-symptom relationships, multiple citrus leprosis disease tissues were collected from the seven citrus cultivars (grapefruit, lime, lemon, mandarin, sour orange, sweet lime, and sweet orange) and the virus associated with the symptoms was identified (Fig. 1). The most typical CiLV-N lesions were observed in citrus-leprosisaffected leaves of mandarin, whereas symptoms observed in citrusleprosis-affected leaves of grapefruit, lemon, and lime (Fig. 1E-G) were intermediate between symptoms typical of CiLV-C (Fig. 1A) and CiLV-N (Fig. 1H). Sweet orange, sour orange, and sweet lime leaves infected with CiLV-N produced large lesions with greenish central chlorotic lesions surrounded by distinct yellow haloes (Fig. 1B-D).
Preliminary identification of CiLV-N using DAS-ELISA, TEM, and RT-PCR. Citrus leprosis disease tissues were tested for CiLV-C and recently reported CiLV-C2 utilizing CiLV-C- and -C2 specific PAbs in DAS-ELISA (7) and unpublished results. The absorbance $\left(\mathrm{OD}_{405}\right)$ values of suspected CiLV tissues after $1 \mathrm{~h}$ of incubation period were recorded from $0.087 \pm 0.002$ to $0.102 \pm 0.004$, and were similar to the healthy control $(0.112 \pm 0.003)$. Serological reactions with the same antibody and CiLV-C isolates from Mexico and CiLV-C2 isolates from Colombia had $\mathrm{OD}_{405}$ values of $0.612 \pm$ 0.006 and $0.804 \pm 0.014$, respectively, after a 30-min incubation period. In contrast, the citrus leprosis disease tissue from Querétaro, Mexico reacted with OFV antiserum at the recommended dilution of 1:500 with an $\mathrm{OD}_{405}$ value of $0.453 \pm 0.009$.

Ultrathin sections of the suspected CiLV-N leaf samples contained bacilliform or bullet-shaped virions ( 20 to 30 by 120 to $135 \mathrm{~nm}$ ) (Fig. $2 \mathrm{~A}-\mathrm{C}$ ), whereas no particles were observed when leaf sections of asymptomatic mandarin orange were examined. Most of the particles were present in the nucleus, and some were in the cytoplasm of the infected leaf tissues. The virions in the cytoplasm were present in a pattern of "spoke wheel" structures typical of many Brevipalpus mitetransmitted viruses (BrTV-N) (Fig. 2C). Morphologically and structurally, these virions were very similar to those of CiNSV, CoRSV, and OFV observed in bitter orange (C. aurantium) (9), Chenopodium quinoa (41), and Tetragonia expansa, respectively (23).
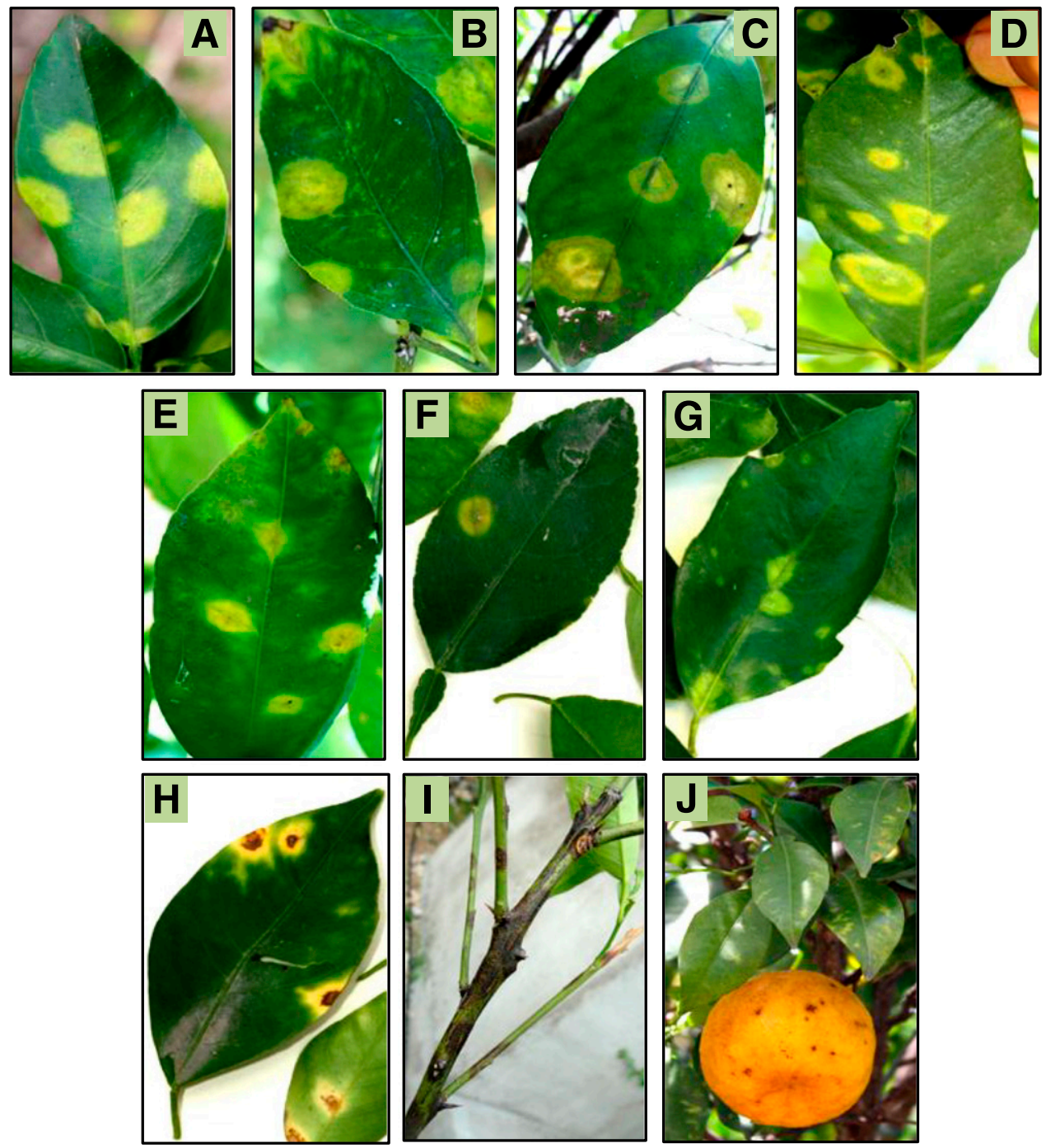

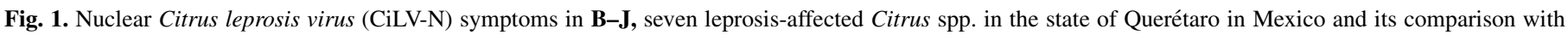

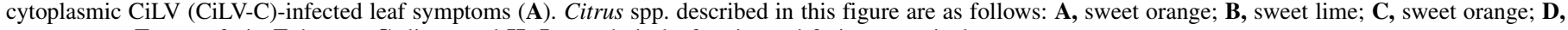
sour orange; E, grapefruit; F, lemon; G, lime; and H-J, mandarin leaf, twig, and fruit, respectively. 
Virus-specific RT-PCR assays were utilized $(28,45)$ to assess the presence of the cytoplasmic CiLVs in the Mexican samples. No amplicons specific to either CiLV-C or CiLV-C2 were produced from either the citrus leprosis disease tissues or samples from healthy citrus. In addition, HGSV-2-specific primers (34) and the newly developed RT-PCR primer sets specific to the hibiscusinfecting Cilevirus sp. (KC626783) and OFV (AB244417) also were utilized. None of the primer sets produced amplicons from symptomatic or healthy samples.

The ELISA and TEM results indicated that the causal agent of the leprosis symptoms observed in Querétaro, Mexico had close serological and morphological similarities to OFV but the results of the RT-PCR assays demonstrated that the nucleotide sequence was distinct from that of OFV and the other tested viruses.

Determination of the nucleotide sequence of $\mathrm{CiLV}-\mathrm{N}$ in Mexico using sRNA NGS. The suspected CiLV-N genome was sequenced using NGS and sRNA from the mandarin and navel sweet orange plants that had symptoms of citrus leprosis disease but failed to react with the available reagents specific for all known leprosis-associated viruses. Total RNA of CiLV-N-infected leaves was isolated and pooled and two sRNA libraries (GUB5, which includes isolate M2345, and GUB6, which includes isolate N16810) were prepared. The libraries contained a total of $24,311,604$ sRNA single-end raw reads that ranged from 18 to $44 \mathrm{nt}$. Of these reads, $76.72 \%$ were mapped to the sweet orange genome, whereas the remaining $23.28 \%$ were not mapped to the sweet orange genome in the database (accession AJPS00000000). After subtraction of citrus genomic sequences, the remaining sequences were assembled and aligned to the nearest plant virus sequences available in the GenBank. Bowtie software was used to align these 5.6 million reads against known plant viruses, and 450,178 mapped reads aligned with either RNA1 or RNA2 sequences of OFV or Citrus tristeza virus (CTV). In total, 49 and 57 virus contigs were obtained from libraries GUB5 and GUB6, respectively. The number of virus contigs was reduced from 49 to 27 and 57 to 23 when contigs of CTV were subtracted from GUB-5 and GUB-6, respectively. The remaining contigs were annotated using BlastX and the nonredundant protein database at NCBI, and all 50 contigs matched the OFV genome in the database. In summary, $1.85 \%$ of the total NGS reads with read lengths of 20 to 22 bases were identified as CiLV-N sequences.

After the CiLV-N sequences were assembled, the data obtained from sRNA libraries provided coverage of approximately $49.5 \%$ of RNA1 and $47.0 \%$ of RNA2. The six ORFs of OFV-RNA1 and-RNA2 coverage rates were $41 \%$ (ORF1), 98\% (ORF2), 62\% (ORF3), $66 \%$ (ORF4), 29\% (ORF5), and 48\% (ORF6). RT-PCR primers were designed to close the gaps and the anticipated amplification products were obtained (Table 1). The amplicons needed to close the gaps were cloned, sequenced, and aligned with sRNA NGS data. Less than $1 \%$ nucleotide variation was found between Sanger and sRNA sequence data; thus, the complete genome sequence of CiLV-N, excluding 5' and 3' UTRs, was obtained. Overall, 60 and $18 \%$ of the $3^{\prime}$ UTR sequences of RNA1 and RNA2, respectively, were aligned with the sRNA NGS data but no 5' UTR sequences were found. In total, 91 and $151 \mathrm{nt}$ that were missing from RNA1 and RNA2, respectively, in the NGS contigs were amplified using 5' UTR RACE. In addition, 3' UTRs of RNA1 (56 nt) and RNA2 (31 nt) were obtained by $3^{\prime}$ UTR RACE to complete the CiLV-N genome.

Analysis of the CiLV-N genome. The genome of CiLV-N RNA1 was composed of the five nonoverlapping ORFs in the order of leader (1) to trailer (t) sequence ( $\left.3^{\prime}-1-N-P-M P-M-G-t-5^{\prime}\right)$ whereas RNA2 consisted of only one ORF that encoded the $\mathrm{L}$ protein in the order of 3'-1-L-t-5'. Comparison of the actual sizes and positions of CiLV-N ORFs and $3^{\prime}$ and 5' UTRs with the genome of other bipartite nucleorhabdoviruses were shown in Supplementary Table S1.

ORF 1: $\mathbf{N}$ gene. The $\mathrm{N}$ protein gene sequence contained a single ORF of 1,353 nt. The translated N protein (AGN91968) contained 450 amino acids (aa), with a molecular mass of $49.27 \mathrm{kDa}$ and an isoelectric point (pI) of 5.78. A nucleotide sequence comparison showed $91 \%$ identity to the $\mathrm{N}$ gene sequence of $\mathrm{OFV}$ (GenBank accessions AB244417 and AB516442). In addition, the amino acid sequence alignment with other rhabdoviruses revealed that the N protein of CiLV-N clearly had the greatest similarity with the proposed genus Dichorhavirus. The corresponding proteins of CiNSV (AGQ21972) and OFV (YP001294924 and BAH97109) shared greatest amino acid identities (98\%) with CiLV-N followed by CoRSV (AHH44825) (51\%). All other N protein sequences from monopartite nucleorhabdovirus in GenBank shared only 24 to $28 \%$ sequence identity with CiLV-N. Thus, this analysis revealed more similarity with Dichorhavirus N proteins than with those from nucleorhabdoviruses. The $\mathrm{N}$ protein contained two putative $\mathrm{N}$-glycosylation sites (amino acids 203 and 310) and contained numerous putative serine (S), threonine (T), and tyrosine (Y) kinase phosphorylation sites. Within the central region of this protein, the sequences YICLSLMRLAVK (amino acids 222 to 233) and FNQCDDLK (amino acids 277 to 284) were highly conserved among CiLV-N, OFV, CiNSV, and CoRSV. Similar sequences, conserved among all known Dichorhavirus spp., were also observed at amino acid positions 310 to 317 and 379 to 386 .

ORF2: Putative phosphoprotein gene. ORF2 contained $714 \mathrm{nt}$ (nucleotides 1,733 to 2,446) and encoded a hypothetical protein of $237 \mathrm{aa}$, with a theoretical molecular mass of $26.5 \mathrm{kDa}$ and a pI of 6.97 (AGN91969). The nucleotide sequence of ORF2 of CiLV-N had 91 and $97 \%$ sequence identity with ORF2 of OFV and
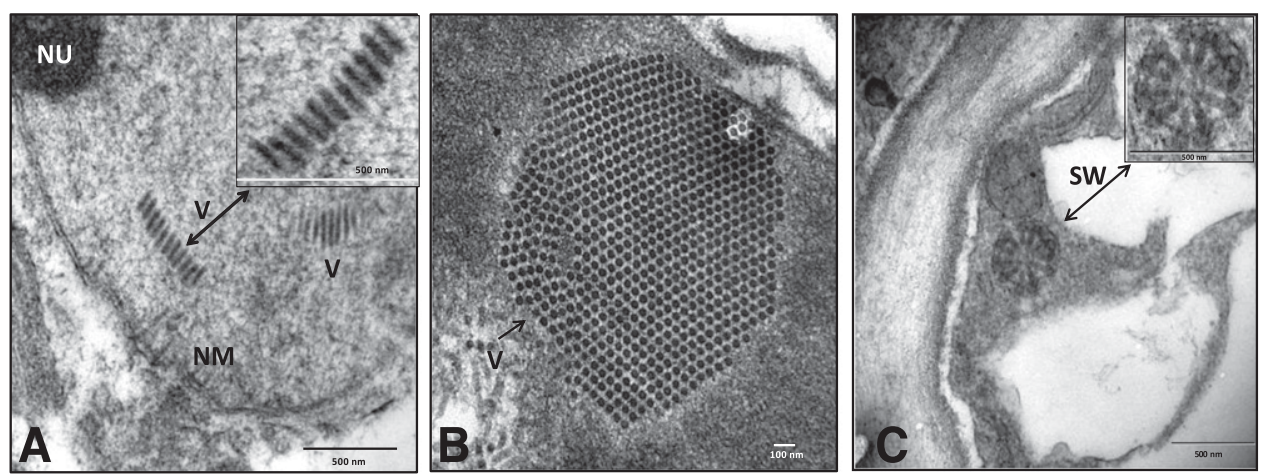

Fig. 2. Transmission electron micrographs of nuclear Citrus leprosis virus (CiLV-N)-infected cells obtained from the state of Querétaro in Mexico. A, Nucleus containing bullet-shaped CiLV-N virions. The boxed area is an enlarged view of CiLV-N virions. NM and NU are the nuclear membrane and nucleolus, respectively. B, Transverse section of a typical lesion from a citrus-leprosis-diseased mandarin leaf tissue showing the stacks of virus particles (V) and $\mathbf{C}$, arrangement of rod-shaped virus particles showing the spokewheel (SW)-like configurations in the cytoplasm of the CiLV-N-infected leaf. The boxed area is an enlarged view of SW arrangement. 
CiNSV, respectively. This putative phospho $(\mathrm{P})$ protein sequence showed the least amount of conservation when compared with other rhabdovirus proteins. The $\mathrm{P}$ protein sequence of CiLV-N shared the highest amino acid sequence identity (97\%) with the $\mathrm{P}$ proteins of CiNSV (AGQ21973) and OFV (YP001294925; BAH97110) but only $36 \%$ with the P protein of CoRSV (AHH44826), and had no significant similarity with the $\mathrm{P}$ protein of other rhabdoviruses.

ORF3: Putative MP gene. ORF3 consisted of $1,113 \mathrm{nt}$ (nucleotides 2,582 to 3,694) and encoded a putative MP of 370 aa, with an approximate molecular mass of $41.68 \mathrm{kDa}$ and $\mathrm{pI}$ of 8.31 (AGN91970). The MP gene may correspond to the third nonstructural protein gene of plant rhabdoviruses (61). The greatest nucleotide sequence identity of ORF3 of CiLV-N was found with the MP of CiNSV (97\%), followed by OFV (90\%) and CoRSV (67\%). The CiLV-N MP sequence shared a maximum $95 \%$ amino acid sequence similarity with the MP of CiNSV (AGQ21974) followed by 93\% with OFV (YP001294926; BAH97111) and only $48 \%$ amino acid sequence identity with CoRSV (AHH44827), the most recently added member of the proposed genus Dichorhavirus.

ORF4: Putative matrix protein gene. ORF4 contained 552 nt (nucleotides 3,835 to 4,386) and encoded the putative matrix (M) protein of 183 aa, with a calculated molecular mass of $20 \mathrm{kDa}$ and $\mathrm{pI}$ of 9.27 (AGN91971). ORF4 of OFV and CiNSV shared 90 and $97 \%$ nucleotide sequence similarity, respectively, with ORF4 of CiLV-N. The amino acid sequence of the CiLV-N M protein had $97 \%$ identity with CiNSV (AGQ21975) and 94 to $95 \%$ identity to OFV M protein sequences (YP001294927; BAH97112). The recently deposited sequence of CoRSV (AHH44828) shared a 45\% amino acid sequence identity with the putative $M$ protein, whereas other nucleorhabdoviruses did not have any significant similarity.

ORF5: G gene. ORF5 consisted of 1,659 nt (nucleotides 4,555 to 6,213 ) and encoded a $G$ protein that was 552 aa long, with a predicted molecular mass of $61.52 \mathrm{kDa}$ and $\mathrm{pI}$ of 6.43 (AGN91972). The nucleotide sequence of CiLV-N had 89 and $96 \%$ sequence similarity to the G protein genes of OFV and CiNSV, respectively. The first 32 aa of the most probable signal peptide sequence (MMAPTNQPDTMSIFRSSIILMLSLISGSGALS) contained a hydrophobic region and the predicted peptidase recognition sequence (amino acids 28 to 32 ). The $\mathrm{G}$ protein also contained a predicted C-terminal transmembrane domain region (amino acids 497 to 519) (WALLAALAVLLLWILWKILWLFI) followed by a short cytoplasmic tail (amino acids 520 to 552). These are common characteristics of the $\mathrm{G}$ protein of other rhabdoviruses. Furthermore, rhabdovirus $G$ proteins typically contain two to six potential glycosylation sites (Asn-X-Ser/Thr) (8). The G protein of CiLV-N had two putative N-glycosylation sites, one located at amino acid 363 (predicted with very strong confidence) and another at amino acid 401 (predicted with medium confidence). The $\mathrm{G}$ protein also had 14 cysteine (C) residues. In all, 11 of the $14 \mathrm{C}$ residues were conserved but $1 \mathrm{C}$ residue at amino acid 243 was not conserved among cyto- and nucleorhabdoviruses. The other two $\mathrm{C}$ residues located at amino acid 104 and amino acid 144 were highly conserved among the nucleorhabdoviruses included in this study. The amino acids of the CiLV-N G protein shared 94 to $97 \%$ sequence identity with the G proteins of OFV (YP001294928; BAH97113) and CiNSV (AGQ21976), respectively, but had only $31 \%$ sequence identity with the G protein of CoRSV (AHH44829). The greatest homology to the $\mathrm{G}$ proteins of other nucleorhabdoviruses included in this study was to that of Rice yellow stunt virus (RYSV) (NP620500; BAI79330), with 25 to $26 \%$ amino acid sequence similarity with CiLV-N, whereas other nucleorhabdoviruses shared only 21 to $23 \%$ sequence similarity.

ORF6: L gene. ORF6 on RNA2 contained 5,634 nt (nucleotides 183 to 5,816) and encoded the $\mathrm{L}$ gene. The translated CiLV-N L protein (AGN91973) was 1,877 aa long and had a calculated molecular mass of $211.79 \mathrm{kDa}$ and $\mathrm{pI}$ of 8.08 . The $\mathrm{L}$ protein had a sequence similarity at the nucleotide level of $90 \%$ with OFV and of $96 \%$ with CiNSV. The complete L protein sequences shared highest amino acid similarity with the L proteins of OFV (YP001294929; BAH97114) (97 to 98\%) and CiNSV (AGQ21977) (97\%), followed by $58 \%$ similarity with the L protein of CoRSV (AHH44830), 33 to $38 \%$ similarity with that of other nucleorhabdoviruses, and 29 to $33 \%$ identity with the cytorhabdoviruses. Similar to the L protein of OFV, the CiLV-N L protein also had 10 putative N-glycosylation sites. The RNA-dependent RNA polymerases (RdRp) of the order Mononegavirales share six conserved sequence domains (I to VI) among all members (39). Our analysis showed that domain VI was only partially present in CiLV-N (data not shown) as well as other known members of the genus Dichorhavirus whereas domain III was more conserved among all rhabdoviruses. Four distinct, highly conserved motifs (A, B, C, and D) are found in this domain (39), including the conserved tetrapeptide GDNQ motif found in OFV and other rhabdoviruses (Fig. 3) (23).
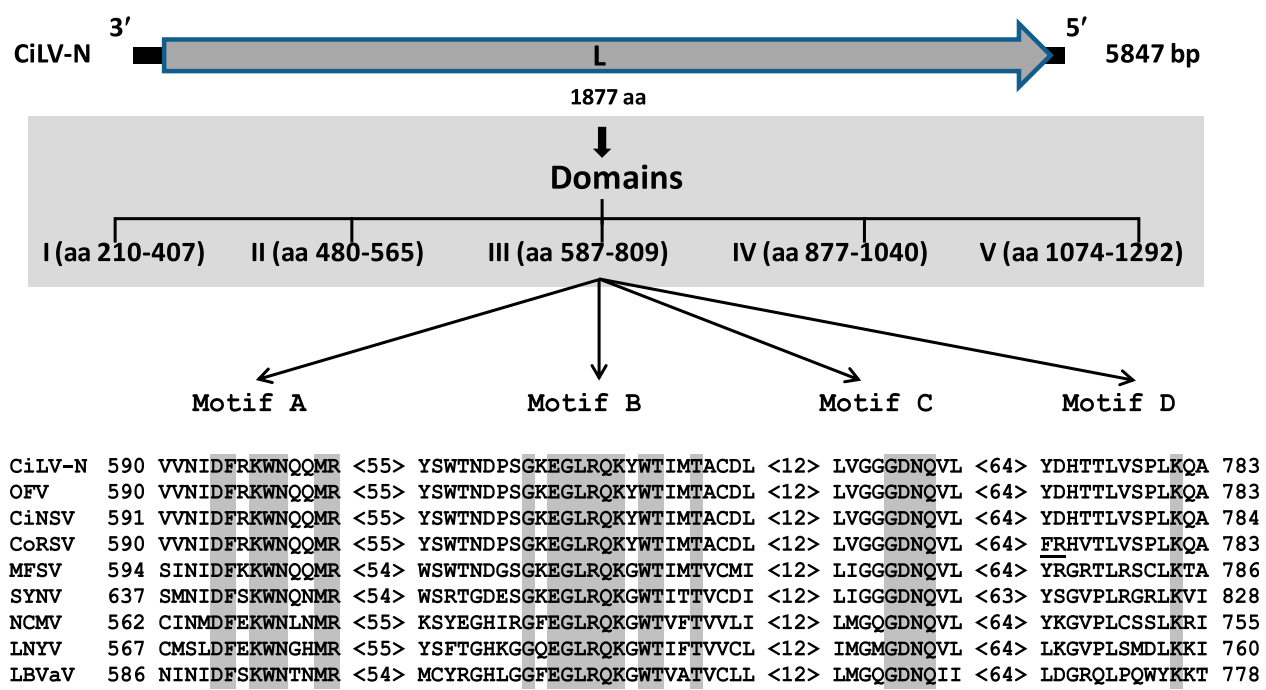

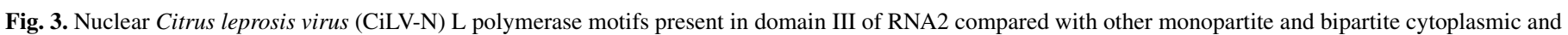

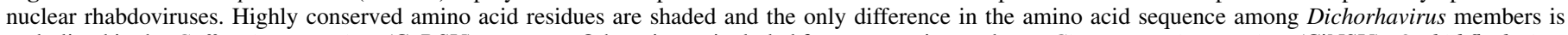

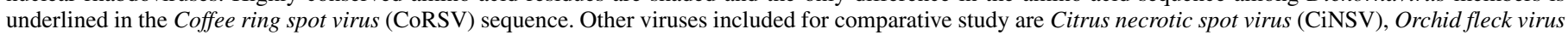

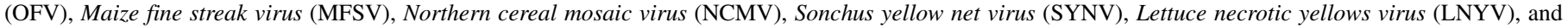
Lettuce big-vein associated virus (LBVaV). 
Analysis of the $3^{\prime}$ and $5^{\prime}$ UTRs of the CiLV-N genome. The CiLV-N genome consisted of two negative-sense singlestranded RNAs: RNA1 (6,268 nt) and RNA2 (5,847 nt). The genome structure and organization of CiLV-N resembled OFV except for the very short $5^{\prime}$ UTRs. The RNA1 and RNA2 molecules had 3' UTRs of 227 and $182 \mathrm{nt}$ and 5' UTRs of only 53 and $31 \mathrm{nt}$ long, respectively. The $3^{\prime}$ UTRs of RNA1 and RNA2 were rich in $\mathrm{A}+\mathrm{U}$ content ( 57 to $59 \%$ ) but the 5' UTRs RNAs were even richer in $\mathrm{A}+\mathrm{U}$ content ( 70 to $86 \%$ ). CiLV-N shared 218 of 227 nt and 176 of $182 \mathrm{nt}$ of the $3^{\prime}$ UTR of RNA1 and RNA2, respectively, with OFV (23). The 3 '-terminal sequences of CiLVN RNA1 and RNA2 shared the first $13 \mathrm{nt}$, with a single mismatch at the ninth nucleotide, whereas the $5^{\prime}$-terminal sequences shared $6 \mathrm{nt}$ at positions three to eight (Supplementary Fig. S1A). The 5' and $3^{\prime}$ ends of both RNAs shared 4 of the first $11 \mathrm{nt}$. The two RNAs had the same 8-nt sequence (UGUGUCCU) at the $3^{\prime}$-terminal region and 6-nt sequence (UUAAAU) at the $5^{\prime}$-terminal region. Although these characteristic features may not be shared with other members of the Dichorhavirus genus, they are often observed in the monopartite cytorhabdoviruses $(56,63)$ and nucleorhabdoviruses $(5,43,57)$. The $3^{\prime}$-terminal sequences of $\mathrm{CiLV}-\mathrm{N}$ were identical to those of OFV whereas the $5^{\prime}$-terminal sequences were dissimilar. Leader $3^{\prime}$ - and trailer $5^{\prime}$-terminal complementary sequences were not found in CiLV-N or other Dichorhavirus spp. such as the Lavras strain of CoRSV (KF812525; KF812526) (41) and the Jal 1 strain of CiNSV (AGQ21972; AGQ21973) (9) (Supplementary Fig. S1B).

The untranslated sequences of RNA1 of CiLV-N, with the exception of the $3^{\prime}$ and $5^{\prime}$ UTRs, totaled 135 to $168 \mathrm{nt}$ in length and contained 58 to $65 \% \mathrm{~A}+\mathrm{U}$. A characteristic consensus sequence ( $3^{\prime}$-UAAAUUUAUUUUGUU/AG/AUU-5') was found among the untranslated sequences present between each ORF (Supplementary Fig. S2A). Part of the consensus sequence was also well conserved among "gene-junction" sequences of other plant rhabdovirus genomes $(14,15,32,42,43,56,57,63)$. Except for the 5 ' trailer region, the gene junction consensus sequence of the CiLV-N RNA1 was mostly identical with that of OFV and CiNSV and comparable with that of the CoRSV gene junction sequences (Supplementary Fig. S2B).

Phylogenetic analysis. To determine the phylogenetic status of Mexican CiLV-N, 33 L protein sequences from plant- and animal-infecting rhabdoviruses were downloaded from NCBI and analyzed. Members of the cyto- and nucleorhabdoviruses are highly divergent from all other rhabdoviruses that infect invertebrates and vertebrates, including mammals. In the cladogram, CiLV-N shared a clade with OFV, the type member of the recently proposed Brevipalpus mite-transmitted genus Dichorhavirus (Fig. 4A). The recently deposited sequences of CiNSV and CoRSV were also clustered with CiLV-N and OFV to form a separate group in the $\mathrm{L}$ protein phylogeny (Fig. 4A). Bootstrap analysis indicated that the branch points of these trees were well supported for phylogenetic classification of plant-infecting rhabdovirus genus, cyto- and nucleorhabdovirus, and Dichorhavirus. Furthermore, neighborjoining and maximum-parsimony phylogenies of the $\mathrm{N}$ and $\mathrm{G}$ proteins of CiLV-N were also constructed with full-length cyto- and nucleorhabdovirus sequences available in GenBank. Phylogenetic and cladistic analyses of the CiLV-N protein $\mathrm{N}$ also revealed that CiLV-N was closely related to OFV. Both CiNSV and CoRSV shared the clade with CiLV-N in the cladogram (Fig. 4B). Similar results were obtained when the $G$ protein cladogram revealed that CiLV-N, CiNSV, OFV, and CoRSV formed a monophyletic clade completely separate from all monopartite nucleorhabdoviruses (Fig. 4C).

Comparison of the genome sequence of CiLV-N with other members of Dichorhavirus and nucleorhabdoviruses. An amino acid similarity plot between viruses was generated using the program PLOTCON using pairwise aligned and concatenated $\mathrm{N}, \mathrm{G}$, and $\mathrm{L}$ amino acids as input into the program. The similarity plots showed that the pairwise alignments of CiLV-N with CiNSV and OFV (Supplementary Fig. S3A and B), respectively, were the most similar of the six viruses compared over the length of the alignment. The most recently added member of the genus Dichorhavirus, the CoRSV (Supplementary Fig. S3C), is most similar to CiLV-N in the conserved portion of the L protein. The similarity plots of CiLV-N with MFSV, SYNV, and PYDV (Supplementary Fig. S3D-F) displayed the same trend.

Detection of CiLV-N from the state of Querétaro, Mexico. Twenty-six tissues from citrus exhibiting leprosis symptoms were collected in the state of Querétaro, Mexico from seven commercial Citrus spp. (grapefruit, lemon, lime, mandarin, sour orange, sweet lime, and sweet orange) to determine whether CiLV-N is consistently associated with specific leprosis symptoms. Primer pairs specific for CiLV-C, CiLV-C2, the CiLV-C2 from hibiscus, and HGSV-2 from 'Volkameriana' lemon $(28,34,45)$ were used to test the symptomatic leaf, fruit, and twig samples by RTPCR. None of these primers produced amplicons from any of the samples. The CiLV-N-specific primer pair CiLV-N-NPF and CiLVN-NPR (46) successfully amplified the partial $\mathrm{N}$ gene amplicon (681 bp) from total RNA of all 26 Mexican citrus leprosis disease samples. Total RNA isolated from a healthy sweet orange leaf, known infected reference isolates of CiLV-C and -C2, the hibiscusinfecting Cilevirus, and HGSV-2 samples also did not produce amplicons with primers for the $\mathrm{N}$ gene sequence of CiLV-N (Fig. 5). All 26 amplicon sequences shared 96 to $99 \%$ nucleotide sequence identity with isolate M2345 of CiLV-N (KF209275) and strain Jal-1 of CiNSV (KF198064) from Mexico. Moreover, a phylogenetic analysis of the $\mathrm{N}$ protein amplicon sequences from the seven Citrus spp. grouped all of the citrus leprosis disease samples from Querétaro state of Mexico in the same clade with the previously sequenced CiLV-N isolates (data not shown).

\section{DISCUSSION}

CiLV-N has been associated with citrus leprosis disease since the middle of the 20th century but no sequence information or molecular data were available (19). Until 2012, CiLV-N was rare and had only been found in the states of São Paulo, Rio Grande do Sul, and Minas Gerais in Brazil and Boquete in Panama (2). Based on the symptoms observed in citrus-leprosis-diseased herbarium leaf samples and analysis of available color photographic records, it was postulated that the citrus leprosis disease in Florida was associated with CiLV-N (21). Very recently, we reported CiLV-N in citrus tissues with symptoms of citrus leprosis disease from Querétaro state of Mexico and deposited the genome sequence in NCBI GenBank (accession numbers KF209275 and KF209276) (50). In this current study, we have now characterized the CiLV-N genome in comparison with the genomes of other related rhabdoviruses. In addition, we also have standardized a specific RT-PCR diagnostic assay for CiLV-N, and applied the recently developed method (46) to differentiate CiLV-N from the cytoplasmic citrus-leprosis-associated viruses.

All known cytoplasmic leprosis virus species-specific and OFVspecific RT-PCR failed to detect virus in the citrus leprosis disease samples from Querétaro, Mexico. Furthermore, PAbs specific for CiLV-C and CiLV-C2 also failed to detect these viruses when used in DAS-ELISA. However, the presence of OFV-like virions in the nucleus of the citrus tissues was confirmed by TEM. The PAb against OFV was used in DAS-ELISA and the results confirmed the presence of a nuclear rhabdovirus in the leprosis samples from Mexico. The combined RT-PCR and PAb ELISA data suggested that the rhabdovirus identified in citrus leprosis disease tissues had a serological relationship with OFV but differed in the genome sequence. We used sRNA NGS to determine the complete genome sequence of the CiLV-N from these samples and aligned it with the genome of the proposed Dichorhavirus OFV sequences. These results suggested that, among the five viruses associated with 


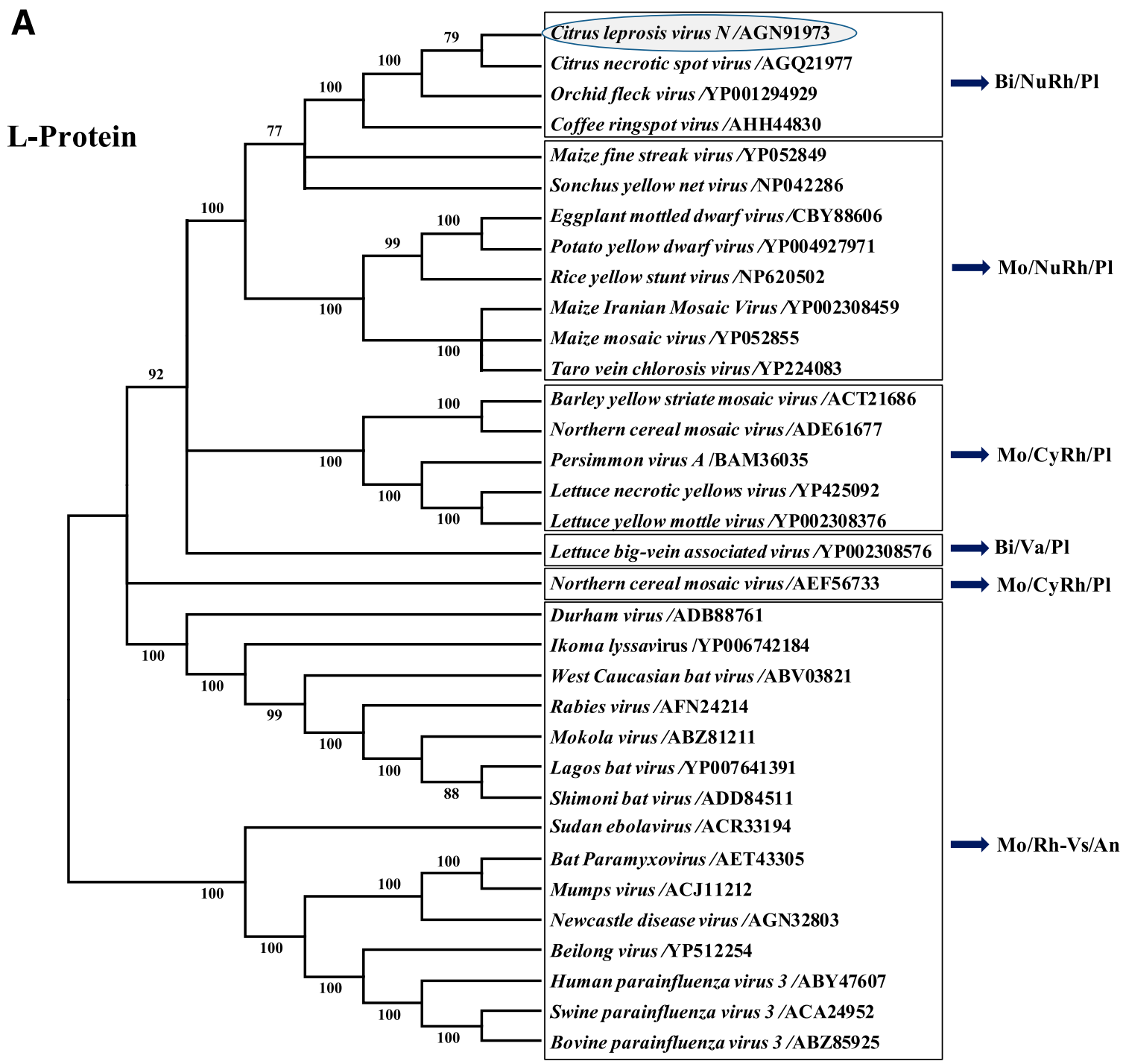

B

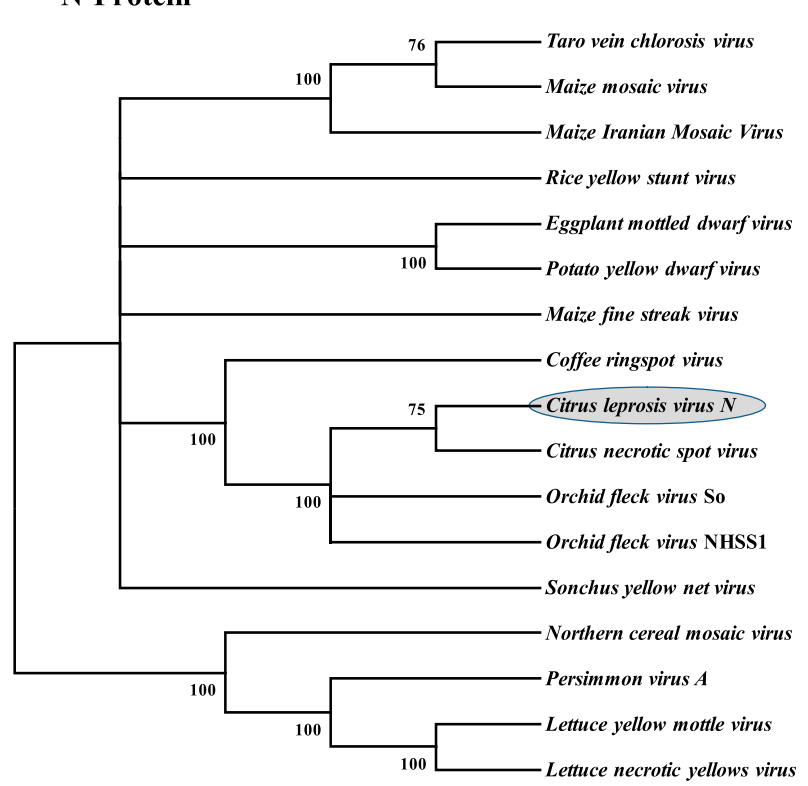

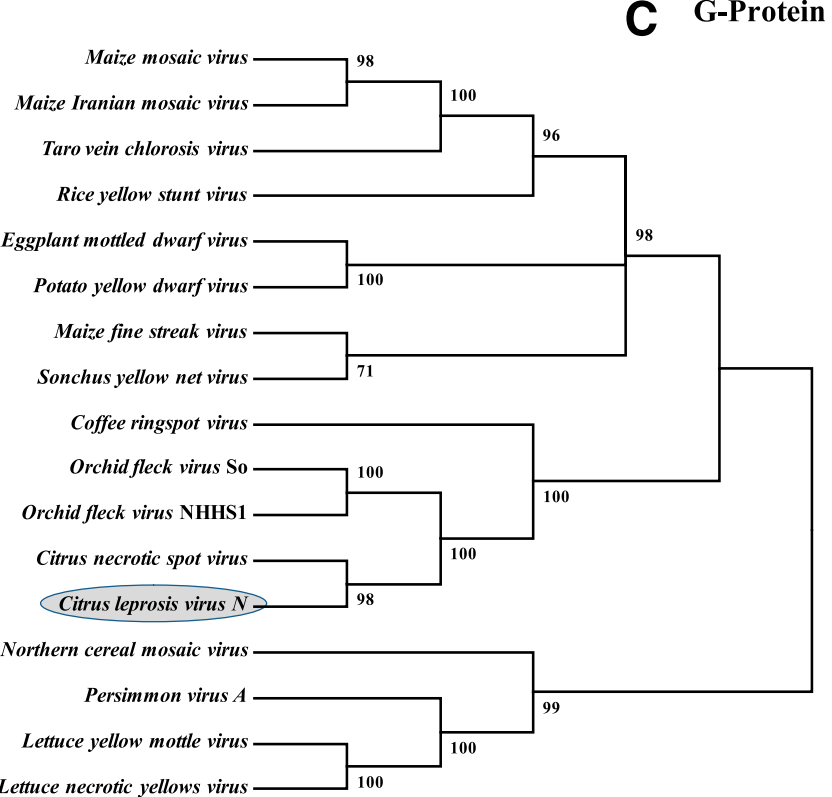

Fig. 4. Cladistic analysis of nuclear Citrus leprosis virus (CiLV-N) with closely related plant and animal rhabdoviruses utilizing conserved proteins A, Polymerase (L protein) from RNA2 and $\mathbf{B}$, nucleocapsid protein $(\mathrm{N})$ and $\mathbf{C}$, glycoprotein $(\mathrm{G})$ from RNA1. Trees were constructed using MEGA6 with neighbor-joining method. Cladogram clades were supported by 1,000 bootstrap replicates. CiLV-N is circled near to Orchid fleck virus, the type member of the genus Dichorhavirus. Monopartitite and bipartite are abbreviated as $\mathrm{Mo}$ and $\mathrm{Bi}$, respectively; genus nucleo- and cytorhabdovirus and varicosavirus are abbreviated as NuRh, CyRh, and Va, respectively; other Rhabdoviridae viruses included in this study abbreviated as Rh-Vs; whereas plant and animal viruses are abbreviated as Pl and An, respectively. 
symptoms of citrus leprosis disease, only CiLV-N was present in the samples from the state of Querétaro in Mexico.

Natural infection of Citrus spp. by OFV has not been reported; however, Citrus hassaku Hort. ex Y. Tan. was experimentally infected, producing chlorotic local lesion symptoms (22). The symptoms in different tissue of citrus-leprosis-diseased plants were similar for CiLV-C, CiLV-C2, or CiLV-N $(2,33,45,50)$. Primers specific for different Citrus leprosis virus types were utilized to determine whether the symptoms observed on naturally infected field-grown Citrus spp. (grapefruit, lime, lemon, mandarin, sour orange, sweet lime, and sweet orange) were specific to one or more leprosis-associated viruses. The recently developed CiLV-N species-specific RT-PCR assay identified CiLV-N from the seven different citrus hosts and established the association of a Dichorhavirus infection. As compared with the previous report (33), typical CiLV-N symptoms, which included necrotic lesions with intermediate orange haloes, were observed only on leprosisinfected mandarin leaves. Slightly necrotic lesions were seen in grapefruit and lemon leaves whereas symptoms more similar to CiLV-C and -C2 were observed in sour orange, sweet lime, and sweet orange even though the plants were infected with only CiLV$\mathrm{N}$ (Fig. 1). Thus, there was no specific lesion type produced by CiLV-N. Rather, the symptoms varied widely depending on host.

The sRNA NGS method was used to assemble 20- to 22-nt sRNA into contigs of the genome sequences of CiLV-N, which were then aligned with the OFV genome. These 20- to 22-nt sRNA fragments accumulated in the citrus-leprosis-diseased tissues due to antiviral defense $(26,64)$. Even though the production of double-stranded RNA substrates for dicer-like proteins is often limited for singlestrand and negative-sense RNA viruses (62), a sufficient population of RNA molecules was present to assemble the genome. These sequences may have been derived from transcribed products, because we were unable to retrieve any sequences from either the 3' UTR of RNA1 and RNA2 or the intergenic regions of CiLV-N. The absence of other virus sequences (except CTV) or viroid sequences in the GUB5 and GUB6 sRNA libraries and prevalence of Brevipalpus spp. with typical leprosis symptoms (46) indicated that the leprosis disease observed in the citrus from Querétaro, Mexico was caused by CiLV-N.

The first complete sequence of a bipartite and negative-sense rhabdovirus-like genome was that of the fungus-transmitted Lettuce big vein associated virus ( $\mathrm{LBVaV})$, the type member of the genus Varicosavirus, of an unassigned family $(51,52,53)$. Furthermore, the discovery of a species of false spider mite (Brevipalpus californicus)-transmitted OFV provided evidence of an unusual bipartite and negative-sense nucleorhabdovirus genome (23). However, phylogenetically, OFV and $\mathrm{LBVaV}$ are more distantly

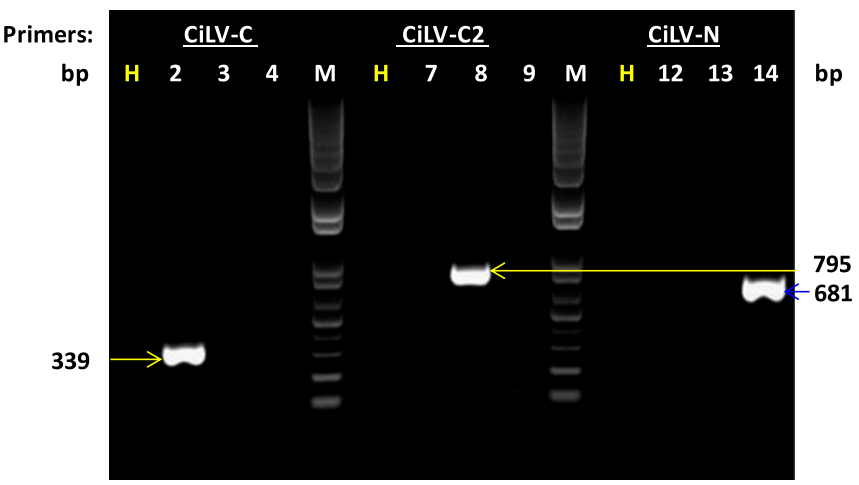

Fig. 5. Specific detection of a 681-nucleotide amplicon in nuclear Citrus leprosis virus (CiLV-N) samples using reverse-transcription polymerase chain reaction. Lane $\mathrm{H}$; healthy citrus; lanes 2, 7, and 12: CiLV-C-infected citrus; lanes 3, 8, and 13: CiLV-C2-infected citrus; lanes 4, 9, and 14: CiLV-Ninfected citrus. Specific primers were used for CiLV-C (lanes 1-4), CiLV-C2 (lanes 6-9), and CiLV-N (lanes 11-14); lane M: 1-kb plus DNA MW ladder (Life Technologies). related than are OFV and other cyto- and nucleorhabdoviruses (23). OFV fits in the group of nuclear BrTV-N (20). CiLV-N is also one of the members of the BrTV-N group and shares particle morphology with OFV, CiNSV, and CoRSV $(3,9,23,41)$.

The structure and organization of the CiLV-N genome demonstrates similarity to those of OFV, and are also comparable with the negative-sense, monopartite Lettuce necrotic yellows virus (LNYV) cytorhabdovirus and SYNV nucleorhabdovirus genomes $(10,17)$. The evolution of the bipartite proposed genus Dichorhavirus may have occurred when a monopartite rhabdovirus RNA genome was split between the G protein (ORF5) and L protein (ORF6). Interestingly, the phylogenetic positioning of LBVaV suggests that such an event could possibly have occurred twice. Taxonomically, CiLV-N shared the genus Dichorhavirus with OFV, CiNSV, CoRSV, and Clerodendrum chlorotic spot virus (11). The Dichorhavirus genomes contain a consensus intergenic gene-junction sequence followed by a characteristic consensus sequence in the untranslated sequences between succeeding ORFs as found in cyto- and nucleorhabdovirus genomes (23).

ORF1 of CiLV-N RNA1 encoded the N gene (p49), which had significant (98\%) amino acid identity with CiNSV and OFV. Hence, the $\mathrm{PAb}$ raised against the $\mathrm{N}$ gene of OFV confirmed a serologically related virus (CiLV-N) in these citrus leprosis disease samples from Querétaro, Mexico. It has been reported that the OFV particles are composed of four structural proteins: N, P, M, and L (24). The putative P, MP, and M proteins of CiLV-N shared 97, 93, and 94 to 95\% amino acid similarity, respectively, with those of OFV but did not share any significant similarities with the corresponding proteins of the rhabdoviruses available in the GenBank other than CoRSV (36 to $48 \%$ amino acid similarity).

The $\mathrm{N}$ protein of CiLV-N contained numerous phosphorylation sites, suggesting that the $\mathrm{N}$ protein might be phosphorylated, as in many rhabdoviruses. The $\mathrm{N}$ protein of OFV was shown to accumulate throughout the cell, while the $\mathrm{P}$ protein accumulated in the nucleus (25). Nuclear accumulation of both the $\mathrm{N}$ and $\mathrm{P}$ proteins of OFV are required for viroplasm formation (25), which is mediated by P-nuclear localization signal (NLS) rather than the N-NLS that are common for all nucleorhabdoviruses $(1,12)$. As we have mentioned, the $\mathrm{P}$ protein of CiLV-N shared $97 \%$ amino acid identity with the $\mathrm{P}$ protein of OFV and the CiLV-N P protein contained a typical P-NLS amino acid sequence (PPPKRKH) at positions of 125 to 131, similar to OFV P protein. This suggests that the P protein of CiLV-N may play a role similar to that documented in OFV.

The hypothetical protein corresponding to the third nonstructural protein gene of plant rhabdoviruses may be involved in cell-to-cell movement (61). The least sequence variation between proteins of CiLV-N and OFV was observed in the MP, which shared $93 \%$ amino acid sequence identity with each other. The aligned MP sequences of all of the present members of the genus Dichorhavirus shared four conserved regions. The sequences between amino acids 50 and 62 (RDEVRETAG/SRRMA) and amino acids 162 and 170 (PVLRDHTVV) in the first half of this putative MP followed, by amino acids 183 to 189 (QYTSSSK) and amino acids 250 to 268 (FPLINPV/AVT/CYCAPGPRFKT) in the central and terminal regions, respectively, are highly conserved among the Brevipalpus mite-transmitted nuclear, bacilliform, bipartite, negative-sense RNA plant viruses (CiLV-N, OFV, CiNSV, and CoRSV). These conserved protein sequences (amino acids 7 to 19) might play a role in the movement of Dichorhavirus spp. between the cells of the viruliferous false spider mite.

The $M$ protein probably interacts with the $G$ protein to stabilize the virus particle and plays an important role in viral morphogenesis (17). The M proteins of the animal rhabdoviruses are required for $\mathrm{N}$ formation (36), and it has been proven that the M protein of OFV plays an important role in maintaining the bullet-shaped conformation of virus particles (24). We found similar-sized bullet-shaped particles of CiLV-N in infected tissue by TEM and predict that the $\mathrm{M}$ protein of CiLV-N plays a similar role. 
Consistent with other nucleorhabdoviruses, CiLV-N ORF5 encodes $\mathrm{G}$ protein, which forms glycoprotein spikes on other fullgrown membrane-bound rhabdovirus virions (17). Dichorhavirus $\mathrm{G}$ proteins are closely related to nucleorhabdovirus $G$ proteins and partially related to cytorhabdovirus $\mathrm{G}$ proteins but unrelated to $\mathrm{G}$ proteins of other rhabdoviruses (Fig. 4C). The CiLV-N G protein contains a predicted peptidase recognition sequence (amino acids 28 to 32) in the hydrophobic region of the putative $\mathrm{N}$-terminal signal peptide, as in other rhabdoviruses. This sequence is probably cleaved during transport to the endoplasmic reticulum (13). G proteins of cyto- and nucleorhabdoviruses contain a minimum of 3 (LNYV) and maximum of 10 (RYSV) potential glycosylation sites (17), whereas CiLV-N contains only 2 glycosylation sites, similar to OFV (23). In addition, the G protein of CiLV-N has 14 cysteine residues, 13 of which are conserved among members of Dichorhavirus and nucleorhabdovirus. In all, 6 of the $13 \mathrm{C}$ residues of the $\mathrm{G}$ protein may contribute to the formation of three intramolecular disulfide bridges that are common to all animal rhabdoviruses $(59,60)$. The alignment of the conserved cysteine domains among plant-infecting rhabdoviruses suggested that the folded structure of the $G$ protein of CiLV-N may not differ significantly from that of other $G$ proteins (data not shown).

As compared with the other proteins of CiLV-N, the L-protein of CiLV-N is more conserved among rhabdoviruses that infect invertebrates and vertebrates, including mammals. Based on the alignment of the conserved L gene polymerase module of Dichorhavirus spp. with that of other plant-infecting rhabdoviruses, CiLV-N appear to be evolutionarily more closely related to other members of the genus Dichorhavirus (58 to 98\%) than to the members of the nucleo- (33 to 38\%) and cytorhabdoviruses (29 to $33 \%$ ) (Fig. 4A). The presence of five complete domains (I to V) in CiLV-N-RNA2 as found in members of the order Mononegavirales suggested that these sequences may have a specific RdRp function similar to other negative-sense viruses (54). Moreover, the presence of the conserved tetrapeptide GDNQ sequence in motif $\mathrm{C}$ of domain III (Fig. 3) is thought to represent the catalytic center and may have a similar polymerase function $(39,40)$. Detailed comparisons of these domains and their conserved motifs confirm that the CiLV-N has the greatest similarity to $\mathrm{OFV}$, and belongs to the proposed genus Dichorhavirus in the family Rhabdoviridae.

Kondo et al. (23) reported the phylogenetic relationships of OFV as an unclassified bipartite rhabdovirus. Neighbor-joining analysis of the $\mathrm{N}$ and $\mathrm{L}$ genes suggested a distant phylogenetic relationship with monopartite nucleorhabdoviruses RYSV, SYNV, or MFSV $(23,38)$. The deduced amino acid sequences of the N, G, and L proteins of CiLV-N and OFV shared 94 to $98 \%$ identity, indicating a close relationship. In addition, both viruses are bipartite, share the same genome organization, and are transmitted by Brevipalpus spp. Phylogenetic and cladistic analyses of the $\mathrm{N}$ and $\mathrm{G}$ proteins of CiLV-N-RNA1 and the L protein of CiLV-N-RNA2 consistently demonstrated a monophyletic origin with OFV and formed a distinct clade with two additional Dichorhavirus spp., CiNSV and CoRSV (Fig. 4A-C). The similarity plot also indicated greatest similarity of CiLV-N with OFV and CiNSV followed by CoRSV, with enhanced divergence between CiLV-N and studied nucleorhabdoviruses. Among the three conserved genes N, G, and L, plant-infecting rhabdoviruses with the greatest regions of similarity corresponded to the conserved $\mathrm{L}$ protein. Based on amino acid identity and cladistic analyses using the maximum parsimony method, we can hypothesize that CiLV-N may be a citrus strain of OFV rather than a distinct virus (Supplementary Fig. S4A-C). However, if we rely on the neighbor-joining method, we also can justify separating CiLV-N from OFV and hypothesize CiLV-N as a distinct species of the genus Dichorhavirus (Fig. 4A-C). In addition, we do not have any information on infection of citrus by OFVor infection of orchids by CiLV-N; therefore, we need to maintain the separation between these two viruses until Koch's postulates can be tested. In addition, demarcation of species within the genus Dichorhavirus is not feasible based on nucleotide diversity because little sequence information is currently available in the GenBank for this proposed genus (11). Furthermore, in the future, other CiLV-N isolate sequence data from multiple Citrus spp. and different countries (Brazil, Colombia, Mexico, and Panama) will help the International Committee on Virus Taxonomy to determine the actual taxonomic position and suggest an acceptable name for CiLV-N if the present nomenclature is to be abandoned.

In conclusion, the phylogenetic relationships among CiLV-N, CiNSV, CoRSV, and OFV demonstrate that Dichorhavirus spp. are restricted mostly to the Americas (i.e., North, Central, and South America), with the exception of OFV, which is also present in Asia, Australia, and Europe, due to the extensive international trade of orchids. However there has been no report of natural infection of citrus or other plant species by OFV $(22,38)$. In the near future, we anticipate that the application of NGS with the use of advanced bioinformatic tools will add complete genome sequences to the database for a second type of OFV and CiLV-N isolates $(38,49)$ as well as other unassigned or newly discovered BrTV-N viruses. Further analyses of these new viruses will lead a better understanding of the evolution of plant-infecting rhabdoviruses.

\section{ACKNOWLEDGMENTS}

We thank M. G. Leon, Centro de Investigación La Libertad, CORPOICA, Villavicencio, Colombia, for providing the CiLV-C2 infected samples; M. J. Melzer, University of Hawaii, Honolulu, for providing the total RNA of hibiscus infecting Cilevirus and HGSV-2; and H. Kondo, Institute of Plant Science and Bio resources, Okayama University, Kurashiki, Japan, for providing OFV antisera, used in this study. This research was financially supported by the USDA-APHIS-PPQ cooperative agreement 11-8130-1246 and Citrus Research \& Development Foundation grant 405.

\section{LITERATURE CITED}

1. Anderson, G., Wang, R., Bandyopadhyay, A., and Goodin, M. 2012. The nucleocapsid protein of Potato yellow dwarf virus: Protein interactions and nuclear import mediated by a non-canonical nuclear localization signal. Front. Plant Sci. 3:14.

2. Bastianel, M., Novelli, V. M., Kitajima, E. W., Kubo, K. S., Bassanezi, R. B., Machado, M. A., and Freitas-Astúa, J. 2010. Citrus leprosis: Centennial of an unusual mite-virus pathosystem. Plant Dis. 94:284-292.

3. Chagas, C. M., Kitajima, E. W., and Rodrigues, J. C. 2003. Coffee ringspot virus vectored by Brevipalpus phoenicis (Acari: Tenuipalpidae) in coffee. Exp. Appl. Acarol. 30:203-213.

4. Childers, C. C., Rodrigues, J. C., Derrick, K. S., Achor, D. S., French, J. V., Welbourn, W. C., Ochoa, R., and Kitajima, E. W. 2003. Citrus leprosis and its status in Florida and Texas: Past and present. Exp. Appl. Acarol. 30: 181-202.

5. Choi, T. J., Wagner, J. D., and Jackson, A. O. 1994. Sequence analysis of the trailer region of sonchus yellow net virus genomic RNA. Virology 202:33-40.

6. Choudhary, N., Roy, A., Govindarajulu, A., Nakhla, M. K., Levy, L., and Brlansky, R. H. 2014. Production of monoclonal antibodies for detection of Citrus leprosis virus $C$ in enzyme-linked immuno-assays and immunocapture reverse transcription-polymerase chain reaction. J. Virol. Methods 206:144-149.

7. Choudhary, N., Roy, A., Guillermo, L. M., Picton, D. D., Wei, G., Nakhla, M. K., Levy, L., and Brlansky, R. H. 2013. Immunodiagnosis of Citrus leprosis virus $C$ using a polyclonal antibody to an expressed putative coat protein. J. Virol. Methods 193:548-553.

8. Coll, J. M. 1995. The glycoprotein G of rhabdoviruses. Arch. Virol. 140: 827-851.

9. Cruz-Jaramillo, J. L., Ruiz-Medrano, R., Rojas-Morales, L., LopezBuenfil, J. A., Morales-Galvan, O., Chavarin-Palacio, C., Ramirez-Pool, J. A., and Xoconostle-Cazares, B. 2014. Characterization of a proposed dichorhavirus associated with the citrus leprosis disease and analysis of the host response. Viruses 6:2602-2622.

10. Dietzgen, R. G., Callaghan, B., Wetzel, T., and Dale, J. L. 2006. Completion of the genome sequence of Lettuce necrotic yellows virus, type species of the genus Cytorhabdovirus. Virus Res. 118:16-22.

11. Dietzgen, R. G., Kuhn, J. H., Clawson, A. N., Freitas-Astua, J., Goodin, M. M., Kitajima, E. W., Kondo, H., Wetzel, T., and Whitfield, A. E. 2014. Dichorhavirus: A proposed new genus for Brevipalpus mite-transmitted, 
nuclear, bacilliform, bipartite, negative-strand RNA plant viruses. Arch. Virol. 159:607-619.

12. Goodin, M. M., Austin, J., Tobias, R., Fujita, M., Morales, C., and Jackson, A. O. 2001. Interactions and nuclear import of the $\mathrm{N}$ and $\mathrm{P}$ proteins of Sonchus yellow net virus, a plant nucleorhabdovirus. J. Virol. 75:9393-9406.

13. Gubala, A. J., Proll, D. F., Barnard, R. T., Cowled, C. J., Crameri, S. G., Hyatt, A. D., and Boyle, D. B. 2008. Genomic characterisation of Wongabel virus reveals novel genes within the Rhabdoviridae. Virology 376: 13-23.

14. Heaton, L. A., Hillman, B. I., Hunter, B. G., Zuidema, D., and Jackson, A. O. 1989. Physical map of the genome of sonchus yellow net virus, a plant rhabdovirus with six genes and conserved gene junction sequences. Proc. Natl. Acad. Sci. USA 86:8665-8668.

15. Huang, Y., Zhao, H., Luo, Z., Chen, X., and Fang, R. X. 2003. Novel structure of the genome of Rice yellow stunt virus: Identification of the gene 6-encoded virion protein. J. Gen. Virol. 84:2259-2264.

16. Izquierdo Castillo, I., Zermeño Diaz, L. F., Mendez, W., Otero-Colina, G., Freitas-Astúa, J., Locali-Fabris, E. C., de Moraes, G. J., Calegario, R. F., Tassi, A. D., and Kitajima, E. W. 2011. Confirmation of the presence of the Citrus leprosis virus $C(\mathrm{CiLV}-\mathrm{C})$ in Southern Mexico. Trop. Plant Pathol. 36:400-403.

17. Jackson, A. O., Dietzgen, R. G., Goodin, M. M., Bragg, J. N., and Deng, M. 2005. Biology of plant rhabdoviruses. Annu. Rev. Phytopathol. 43: 623-660.

18. Kim, S. R., Yoon, J. Y., Choi, G. S., Chang, M. U., Choi, J. K., and Chung, B. N. 2010. Molecular characterization and survey of the infection rate of Orchid fleck virus in commercial orchids. Plant Pathol. J. 26:130-138.

19. Kitajima, E. W., Muller, G. W., Costa, A. S., and Yuki, W. 1972. Short, rod-like particles associated with citrus leprosis. Virology 50:254-258.

20. Kitajima, E. W., Rodrigues, J. C. V., and Freitas-Astua, J. 2010. An annotated list of ornamentals naturally found infected by Brevipalpus mitetransmitted viruses. Sci. Agric. 67:348-371.

21. Kitajima, E. W., Chagas, C. M., Harakava, R., Calegario, R. F., FreitasAstúa, J., Rodrigues, J. C. V., and Childers, C. C. 2011. Citrus leprosis in Florida, USA, appears to have been caused by the nuclear type of Citrus leprosis virus (CiLV-N). Virus Rev. Res. 16:1-5.

22. Kondo, H., Maeda, T., and Tamada, T. 2003. Orchid fleck virus: Brevipalpus californicus mite transmission, biological properties and genome structure. Exp. Appl. Acarol. 30:215-223.

23. Kondo, H., Maeda, T., Shirako, Y., and Tamada, T. 2006. Orchid fleck virus is a rhabdovirus with an unusual bipartite genome. J. Gen. Virol. 87: 2413-2421.

24. Kondo, H., Maeda, T., and Tamada, T. 2009. Identification and characterization of structural proteins of Orchid fleck virus. Arch. Virol. 154:37-45.

25. Kondo, H., Chiba, S., Andika, I. B., Maruyama, K., Tamada, T., and Suzuki, N. 2013. Orchid fleck virus structural proteins N and P form intranuclear viroplasm-like structures in the absence of viral infection. J. Virol. 87:7423-7434.

26. Kreuze, J. F., Perez, A., Untiveros, M., Quispe, D., Fuentes, S., Barker, I., and Simon, R. 2009. Complete viral genome sequence and discovery of novel viruses by deep sequencing of small RNAs: A generic method for diagnosis, discovery and sequencing of viruses. Virology 388:1-7.

27. Langmead, B., Trapnell, C., Pop, M., and Salzberg, S. L. 2009. Ultrafast and memory-efficient alignment of short DNA sequences to the human genome. Genome Biol. 10:R25.

28. Locali, E. C., Freitas-Astua, J., de Souza, A. A., Takita, M. A., AstuaMonge, G., Antonioli, R., Kitajima, E. W., and Machado, M. A. 2003. Development of a molecular tool for the diagnosis of leprosis, a major threat to citrus production in the Americas. Plant Dis. 87:1317-1321.

29. Locali-Fabris, E. C., Freitas-Astua, J., Souza, A. A., Takita, M. A., AstuaMonge, G., Antonioli-Luizon, R., Rodrigues, V., Targon, M. L., and Machado, M. A. 2006. Complete nucleotide sequence, genomic organization and phylogenetic analysis of Citrus leprosis virus cytoplasmic type. J. Gen. Virol. 87:2721-2729.

30. Loconsole, G., Onelge, N., Potere, O., Giampetruzzi, A., Bozan, O., Satar, S., De Stradis, A., Savino, V., Yokomi, R. K., and Saponari, M. 2012. Identification and characterization of Citrus yellow vein clearing virus, a putative new member of the genus Mandarivirus. Phytopathology 102: $1168-1175$.

31. Loconsole, G., Saldarelli, P., Doddapaneni, H., Savino, V., Martelli, G. P., and Saponari, M. 2012. Identification of a single-stranded DNA virus associated with citrus chlorotic dwarf disease, a new member in the family Geminiviridae. Virology 432:162-172.

32. Luo, Z. L., and Fang, R. X. 1998. Structure analysis of the rice yellow stunt rhabdovirus glycoprotein gene and its mRNA. Arch. Virol. 143:2453-2459.

33. Marques, J. P., Kitajima, E. W., Freitas-Astua, J., and Appezzato-da-Gloria, B. 2010. Comparative morpho-anatomical studies of the lesions caused by Citrus leprosis virus on sweet orange. An. Acad. Bras. Cienc. 82:501-511.
34. Melzer, M. J., Sether, D. M., Borth, W. B., and Hu, J. S. 2012. Characterization of a virus infecting Citrus volkameriana with citrus leprosis-like symptoms. Phytopathology 102:122-127.

35. Melzer, M. J., Simbajon, N., Carillo, J., Borth, W. B., Freitas-Astua, J., Kitajima, E. W., Neupane, K. R., and Hu, J. S. 2013. A cilevirus infects ornamental hibiscus in Hawaii. Arch. Virol. 158:2421-2424.

36. Newcomb, W. W., and Brown, J. C. 1981. Role of the vesicular stomatitis virus matrix protein in maintaining the viral nucleocapsid in the condensed form found in native virions. J. Virol. 39:295-299.

37. Pascon, R. C., Kitajima, J. P., Breton, M. C., Assumpcao, L., Greggio, C., Zanca, A. S., Okura, V. K., Alegria, M. C., Camargo, M. E., Silva, G. G., Cardozo, J. C., Vallim, M. A., Franco, S. F., Silva, V. H., Jordao, H., Jr., Oliveira, F., Giachetto, P. F., Ferrari, F., Aguilar-Vildoso, C. I., Franchiscini, F. J., Silva, J. M., Arruda, P., Ferro, J. A., Reinach, F., and da Silva, A. C. 2006. The complete nucleotide sequence and genomic organization of citrus leprosis associated virus, cytoplasmatic type (CiLV-C). Virus Genes 32:289-298.

38. Peng, D. W., Zheng, G. H., Zheng, Z. Z., Tong, Q. X., and Ming, Y. L. 2013. Orchid fleck virus: An unclassified bipartite, negative-sense RNA plant virus. Arch. Virol. 158:313-323.

39. Poch, O., Blumberg, B. M., Bougueleret, L., and Tordo, N. 1990. Sequence comparison of five polymerases ( $\mathrm{L}$ proteins) of unsegmented negative-strand RNA viruses: Theoretical assignment of functional domains. J. Gen. Virol. 71:1153-1162.

40. Poch, O., Sauvaget, I., Delarue, M., and Tordo, N. 1989. Identification of four conserved motifs among the RNA-dependent polymerase encoding elements. EMBO J. 8:3867-3874.

41. Ramalho, T. O., Figueira, A. R., Sotero, A. J., Wang, R., Geraldino Duarte, P. S., Farman, M., and Goodin, M. M. 2014. Characterization of Coffee ringspot virus-Lavras: A model for an emerging threat to coffee production and quality. Virology 464-465:385-396.

42. Reed, S. E., Tsai, C. W., Willie, K. J., Redinbaugh, M. G., and Hogenhout, S. A. 2005. Shotgun sequencing of the negative-sense RNA genome of the rhabdovirus Maize mosaic virus. J. Virol. Methods 129:91-96.

43. Revill, P., Trinh, X., Dale, J., and Harding, R. 2005. Taro vein chlorosis virus: Characterization and variability of a new nucleorhabdovirus. J. Gen. Virol. 86:491-499.

44. Rodrigues, J. C., Kitajima, E. W., Childers, C. C., and Chagas, C. M. 2003. Citrus leprosis virus vectored by Brevipalpus phoenicis (Acari: Tenuipalpidae) on citrus in Brazil. Exp. Appl. Acarol. 30:161-179.

45. Roy, A., Choudhary, N., Guillermo, L. M., Shao, J., Govindarajulu, A., Achor, D., Wei, G., Picton, D. D., Levy, L., Nakhla, M. K., Hartung, J. S., and Brlansky, R. H. 2013. A novel virus of the genus Cilevirus causing symptoms similar to citrus leprosis. Phytopathology 103:488-500.

46. Roy, A., León, M. G., Stone, A. L., Schneider, W. L., Hartung, J. S., and Brlansky, R. H. 2014. First report of Citrus leprosis virus nuclear type in sweet orange in Colombia. Plant Dis. 98:1162.

47. Roy, A., Shao, J., Hartung, J. S., Schneider, W. L., and Brlansky, R. H. 2013. A case study on discovery of novel Citrus leprosis virus cytoplasmic type 2 utilizing small RNA libraries by next generation sequencing and bioinformatic analyses. J. Data Mining Genomics Proteomics 4:129.

48. Roy, A., Shao, J., Schneider, W. L., Hartung, J. S., and Brlansky, R. H. 2014. Population of endogenous pararetrovirus genomes in Carrizo citrange. Genome Announc. 2:e01063-13.

49. Roy, A., Stone, A., Otero-Colina, G., Schneider, W. L., Hartung, J. S., and Brlansky, R. H. 2014. Genetic variability in the nucleocapsid genes of nuclear Citrus leprosis virus reveals the presence of a distinct species of dichorhavirus. Phytopathology 104:S3.101.

50. Roy, A., Stone, A., Otero-Colina, G., Wei, G., Choudhary, N., Achor, D., Shao, J., Levy, L., Nakhla, M. K., Hollingsworth, C. R., Hartung, J. S., Schneider, W. L., and Brlansky, R. H. 2013. Genome assembly of Citrus leprosis virus nuclear type reveals a close association with Orchid fleck virus. Genome Announc. 1:e00519-13.

51. Sasaya, T., Ishikawa, K., and Koganezawa, H. 2001. Nucleotide sequence of the coat protein gene of Lettuce big-vein virus. J. Gen. Virol. 82:1509-1515.

52. Sasaya, T., Ishikawa, K., and Koganezawa, H. 2002. The nucleotide sequence of RNA1 of Lettuce big-vein virus, genus Varicosavirus, reveals its relation to nonsegmented negative-strand RNA viruses. Virology 297:289-297.

53. Sasaya, T., Kusaba, S., Ishikawa, K., and Koganezawa, H. 2004. Nucleotide sequence of RNA2 of Lettuce big-vein virus and evidence for a possible transcription termination/initiation strategy similar to that of rhabdoviruses. J. Gen. Virol. 85:2709-2717.

54. Schnell, M. J., and Conzelmann, K. K. 1995. Polymerase activity of in vitro mutated rabies virus L protein. Virology 214:522-530.

55. Tamura, K., Stecher, G., Peterson, D., Filipski, A., and Kumar, S. 2013. MEGA6: Molecular Evolutionary Genetics Analysis version 6.0. Mol. Biol. Evol. 30:2725-2729.

56. Tanno, F., Nakatsu, A., Toriyama, S., and Kojima, M. 2000. Complete nucleotide sequence of Northern cereal mosaic virus and its genome organization. Arch. Virol. 145:1373-1384. 
57. Tsai, C. W., Redinbaugh, M. G., Willie, K. J., Reed, S., Goodin, M., and Hogenhout, S. A. 2005. Complete genome sequence and in planta subcellular localization of Maize fine streak virus proteins. J. Virol. 79: 5304-5314.

58. Vives, M. C., Velazquez, K., Pina, J. A., Moreno, P., Guerri, J., and Navarro, L. 2013. Identification of a new enamovirus associated with citrus vein enation disease by deep sequencing of small RNAs. Phytopathology 103:1077-1086.

59. Walker, P. J. 2008. Bovine ephemeral fever virus. Pages 354-362. in: In Encyclopedia of Virology. B. W. J. Mahy and M. H. V. van Regenmortel, eds. Academic Press, Oxford, UK.

60. Walker, P. J., and Kongsuwan, K. 1999. Deduced structural model for animal rhabdovirus glycoproteins. J. Gen. Virol. 80:1211-1220.
61. Walker, P. J., Dietzgen, R. G., Joubert, D. A., and Blasdell, K. R. 2011. Rhabdovirus accessory genes. Virus Res. 162:110-125.

62. Weber, F., Wagner, V., Rasmussen, S. B., Hartmann, R., and Paludan, S. R. 2006. Double-stranded RNA is produced by positive-strand RNA viruses and DNA viruses but not in detectable amounts by negative-strand RNA viruses. J. Virol. 80:5059-5064.

63. Wetzel, T., Dietzgen, R. G., and Dale, J. L. 1994. Genomic organization of lettuce necrotic yellows rhabdovirus. Virology 200:401-412.

64. Wu, Q., Luo, Y., Lu, R., Lau, N., Lai, E. C., Li, W. X., and Ding, S. W. 2010. Virus discovery by deep sequencing and assembly of virus-derived small silencing RNAs. Proc. Natl. Acad. Sci. USA 107:1606-1611.

65. Zerbino, D. R., and Birney, E. 2008. Velvet: Algorithms for de novo short read assembly using de Bruijn graphs. Genome Res. 18:821-829. 